
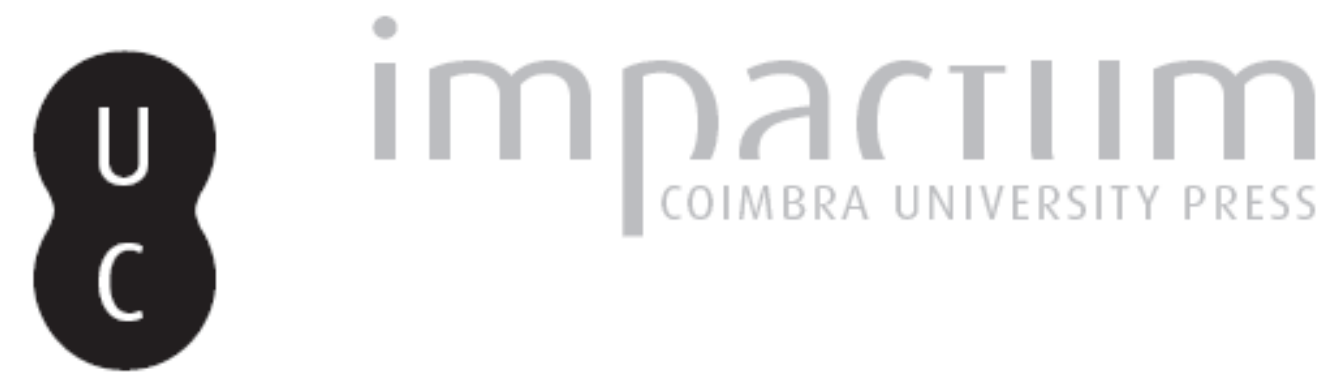

\title{
A concepção de Páthos em relatos híbridos na antiguidade: José e Aseneth e os Actos de Paulo e Tecla
}

\author{
Autor(es): $\quad$ Ipiranga Júnior, Pedro
}

Publicado por: Sociedade Brasileira de Estudos Clássicos

URL persistente:

URI:http://hdl.handle.net/10316.2/37145

DOI:

DOI:http://dx.doi.org/10.14195/2176-6436_26-2_4

Accessed : $\quad$ 26-Apr-2023 14:20:01

A navegação consulta e descarregamento dos títulos inseridos nas Bibliotecas Digitais UC Digitalis, UC Pombalina e UC Impactum, pressupõem a aceitação plena e sem reservas dos Termos e Condições de Uso destas Bibliotecas Digitais, disponíveis em https://digitalis.uc.pt/pt-pt/termos.

Conforme exposto nos referidos Termos e Condições de Uso, o descarregamento de títulos de acesso restrito requer uma licença válida de autorização devendo o utilizador aceder ao(s) documento(s) a partir de um endereço de IP da instituição detentora da supramencionada licença.

Ao utilizador é apenas permitido o descarregamento para uso pessoal, pelo que o emprego do(s) título(s) descarregado(s) para outro fim, designadamente comercial, carece de autorização do respetivo autor ou editor da obra.

Na medida em que todas as obras da UC Digitalis se encontram protegidas pelo Código do Direito de Autor e Direitos Conexos e demais legislação aplicável, toda a cópia, parcial ou total, deste documento, nos casos em que é legalmente admitida, deverá conter ou fazer-se acompanhar por este aviso.

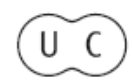




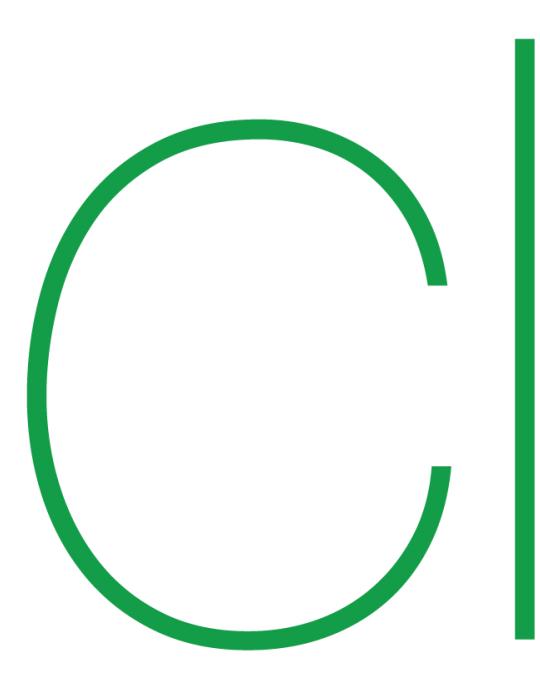

revista brasileira de estudos clássicos
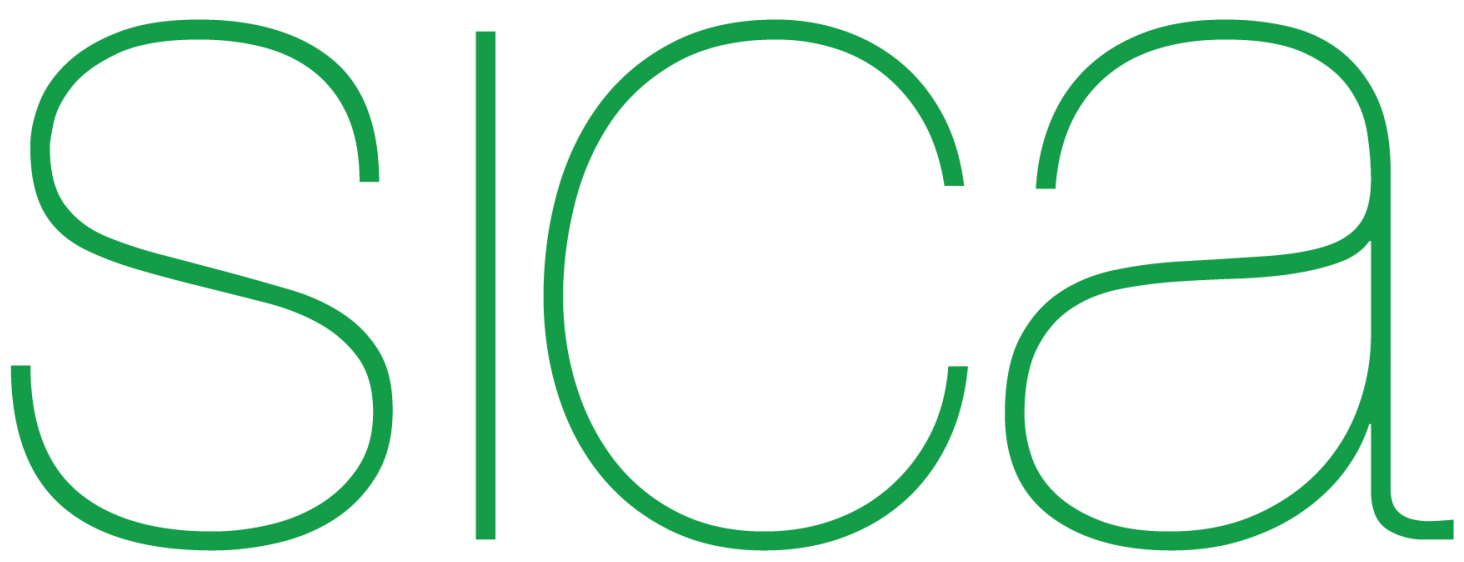

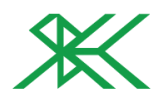

y

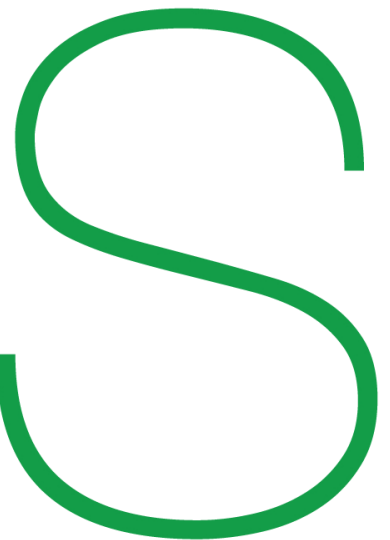




\section{A CONCEPÇÃO DE PÁTHOS EM RELATOS HÍBRIDOS NA ANTIGUIDADE: JOSÉ E ASENETH E OS ATOS DE PAULO E TECLA}

\author{
Pedro Ipiranga Júnior*
}

RESUMO: O presente trabalho se dispõe analisar um corpus de obras que apresentam uma configuração híbrida de dois gêneros: o bíos antigo e o romance antigo. De forma operacional, enfocaremos a concepção de páthos que aparece em duas dessas obras: uma judaica, José e Aseneth, e outra cristã, Os Atos de Paulo e Tecla, comparando-a e confrontando-a com a noçáo de páthos presente num romance grego, por assim dizer, canônico, Quéreas e Calírroe ou simplesmente Calírroe, do escritor do século I d.C. Caríton de Afrodisíade.

PALAVRAS-CHAVE: Romance antigo; biografia na Antiguidade; narrativas híbridas na Antiguidade; o páthos narrativo; José e Aseneth; Os Atos de Paulo e Tecla; Quéreas e Calírroe.

\section{Pétros Pétroi khaírein}

ABSTRACT: This paper sets out to analyze a corpus of works that present a hybrid configuration of two genres: the ancient bios and ancient novel. Operationally, we focus on the design of pathos that appears in two of these works: one Jewish, Joseph and Aseneth, and other Christian The Acts of Paul and Thecla, comparing it and contrasting it with the notion of pathos present in, so to speak, canonical Greek novel, Chaereas and Callirhoe or simply Callirhoe written by Charíton of Aphrodisias of the first century A.D..

KEYWORDS: Ancient novel; biography in Antiquity; hybrid narratives in Antiquity; narrative pathos; Joseph and Aseneth; The Acts of Paul and Thecla; Chaereas and Callirhoe.
*Universidade Federal do Paraná junioripiranga@yahoo.com.br 
1. T. Withmarsh (Ed.), The Cambridge Companion to the Greek and Roman Novel, Cambridge, Cambridge University Press, 2008, p. 2.

2. N. Holzberg, The Ancient Novel. An Introduction, London and New York, Routledge, 1995.

3. S. Tilg, Chariton of Aphrodisias and the Invention of the Greek Love Novel, Oxford, New York, Oxford University Press, 2010.
Empreendo analisar e pôr em paralelo as narrativas em que estão inseridas as seguintes personagens: Thekla, Aseneth, Calírroe. Tais mulheres, personagens históricos e/ou ficcionais, figuram como heroínas de narrativas de índole bastante diferenciadas, aproximadas, todavia, pela ambientação romanesca e por um tipo de emoção ou afecção que as afeta de forma intensa e avassaladora. Esta afecção é expressa como páthos, sofrimento, doença ou emoçáo lancinante, mas também no sentido mais específico de paixão amorosa, que incluía todos os sentidos anteriores, sendo enunciada de modo explícito no contexto do romance grego antigo. Calírroe, por seu turno, é a protagonista do romance grego escrito por Caríton de Afrodísias, provavelmente no século I a.C., ou, mais tardar, na primeira metade do século II d.C. Aseneth é a heroína de uma narrativa romanceada, provavelmente de origem judaica, cuja datação mais aceita a situa no século I ou II d.C. Por sua vez, Tecla é a heroína de relatos conhecidos como Atos Apócrifos dos Apóstolos, no caso, Atos de Paulo e Tecla, provavelmente da segunda metade do século II d.C.

O romance de Caríton, mais conhecido pelo nome Quéreas e Calírroe, faz parte inegavelmente do corpus canônico do romance antigo. Este cânon do romance parece reafirmado na ênfase dada a sete textos, segundo as palavras de Tim Withmarsh $^{1}$, numa publicaçáo de 2008, The Cambridge Companion to the Greek and Roman Novel, quais seriam: em grego, Calirroe ou Quéreas e Calírroe, de Caríton de Afrodisíades, Antia e Habrócomes ou as Efesíacas, de Xenofonte de Éfeso, Leucipe e Clitofonte, de Aquiles Tácio, Dáfnis e Cloé, de Longo, Caricléia e Teágenes ou as Etiópicas de Heliodoro; em latim, Satyrika ou Satyricon, de Petrônio, e as Metamorfoses ou O Asno de Ouro, de Apuleio. A rubrica mais corrente para os romances gregos seria de "romance de amor ideal". Os dois romances latinos são classificados, por exemplo, por Holzberg ${ }^{2}$, como romances do tipo satírico, aí incluído o Asno, possivelmente de Luciano de Samósata, ou como "realistic novel" (romance realista) segundo Stefan Tilg ${ }^{3}$. Cabe mais precisamente a Jacyntho Lins Brandão, já em sua tese de livre-docência, publicada como livro em 2006, com o título $A$ invenção do romance, estabelecer os limites desse corpus do romance antigo, aí acrescentando outra obra de Luciano, Das Narrativas Verdadeiras. Aqui, claro, me abstenho de fazer referência aos fragmentos de obras, 
também consideradas como romance, tais como, As coisas incriveis além da Tule, de Antônio Diógenes, Nino e Sesôncosis, Metíoco e Partênope, as Babilônicas de Jâmblico, As Fenicíacas de Loliano, Iolau, Quione, Calígone, entre outros.

Outros tipos de narrativas, como as que aqui me ocupo, estão colocadas à margem do gênero, na acepção de Holzberg, ou seja, seriam romances marginais em relação ao cânon. Nesse sentido, emprego o termo romance apócrifo, numa definição e classificação, a princípio, meramente negativa relativa ao cânon romanesco, mas retendo tal qualificativo também a partir de seu caráter de apócrifo concernente ao cânon escriturístico. Numa obra relativamente recente sobre romance antigo, Chariton of Aphrodisias and the Invention of the Greek Love, de Stefan Tilg, publicada em 2010, tais obras são mencionadas apenas indiretamente, como "narrativas judaicas e cristãs com interesses transcendentais" ${ }^{4}$.

Então, partindo da análise contextualizada destas obras e da teorização de Jacyntho Lins Brandão sobre o gênero do romance antigo, coloco as seguintes hipóteses: essas narrativas, por assim dizer, marginais vêm a ser um tipo diferenciado de romance (aqui sendo mister verificar por quais parâmetros este gênero é constituído); ou tais narrativas perfazem um gênero híbrido, na medida em que se apropriam de elementos estruturais e temáticos do romance e deles se utilizam numa perspectiva biografizante, resultando num gênero híbrido de biografia e romance.

De início, vou me ater às consideraçóes de Antonio Piñero aduzidas contra a classificação dos Atos Apócrifos dentro do gênero romanesco. Ele parte dos argumentos de Rosa Söder que havia relacionado tais obras com o romance, buscando nelas verificar o que seriam os cinco elementos fundamentais da literatura romanesca, a saber: as viagens, as aretaí (virtudes ou poderes em geral) do herói, o elemento teratológico, o elemento tendencioso e o elemento erótico. Segundo ele, tanto as viagens como o elemento teratológico (ligado ao maravilhoso e aos eventos extraordinários) podem ser advindos mais naturalmente do próprio contexto escriturístico ou meramente das premências e da necessidade de viajar em vista do caráter missionário das ações dos apóstolos 5 . Embora os Atos façam referência, no mais das vezes, aos evangelhos e outros escritos do N.T. e a alguns textos do A.T., o que importa é verificar a forma de utilização e o uso sistemático dos
4. Idem, p. 2-3.

5. A. Piñero, C. Gonzalo (ed.), Hechos Apócrifos de los Apóstoles I. Hechos de Andrés, Juan y Pedro, Madrid, Biblioteca de Autores Cristianos, 2004, p. 37. 
mesmos. Efetivamente, isso se manifesta como uma distinção nítida: assim como o romance de Caríton tem, por exemplo, os poemas homéricos como obra referencial, esses romances apócrifos terão como referência a tradição escriturística. Não obstante, o mais relevante para a discussão de gênero é discernir a forma em que se dá esse tipo de vínculo referencial.

Porquanto, é imprescindível partir da concepção de Brandáo para a definiçáo do romance: em primeiro lugar, seria um tipo de narrativa mimética que explicita o seu caráter de ficção, no sentido forte do termo. Para isso, ele elege como parâmetro ficcional a concepção de pseûdos tal qual é, por assim dizer, teorizada na obra de Luciano de Samósata; o guia de leitura para essa teorizaçáo estaria no prefácio Das Narrativas Verdadeiras, de Luciano de Samósata. A grande novidade dessa definição é que não parte do que seria o romance de amor de tipo ideal, mas se assenta na relaçáo de alteridade que a narrativa de tipo ficcional estabelece com discursos da ordem da verdade, como, por exemplo, a história e a filosofia. Vejamos a passagem:

Por isso eu também, por vanglória tendo me esforçado para deixar algo aos nossos pósteros, a fim de que não seja o único a não participar da liberdade em 'mitologizar' (contar narrativas fictícias), uma vez que não tinha nada de verdadeiro para contar - pois náo tinha experimentado nada digno de relato - voltei-me para o pseûdos (mentira/ficção), de modo muito sensato do que os outros; pois, pelo menos, em uma única coisa serei verdadeiro: dizendo que minto. Assim, eu posso evitar também a acusaçấo dirigida contra os outros, eu próprio confessando nada dizer de verdadeiro. Escrevo, portanto, acerca de coisas que nunca vi, nunca sofri/experienciei, nem soube por outros, e, ademais, sobre coisas que absolutamente, a princípio, năo poderiam ter existido. Por isso, é preciso que os que a lêem/consultam de forma alguma acreditem nelas.

Não cabe aqui uma discussão pormenorizada da tese de Brandão, sendo suficiente apontar algumas coordenadas principais. Segundo ele, Luciano logra criar um estatuto para a ficção, elegendo como princípio o que seria a suma liberdade do poeta de criar pseûdea, cuja "legitimidade vem de sua especificidade discursiva e seu lugar é o da alteridade em face dos discursos 
verdadeiros"'. Por conseguinte, a ficção em prosa, no apogeu do romance no século II d.C., levaria ao ápice a questão da verdade no diálogo da filosofia e da historiografia com a literatura desde o século VI a.C., uma vez que a prosa era, a princípio, destinada aos discursos da ordem do verdadeiro. Luciano ultrapassaria Aristóteles pelo fato de não se ater mais a categorias como o verossímil, que atrelaria seu discurso a alguma ordem do real ou a alguma referenciaçáo ao que poderia ter sido. Num outro opúsculo, Como se deve escrever a história, Luciano traça mais nitidamente as fronteiras do discurso histórico, em funçáo de sua contraposição a qualquer discurso da ordem do pseûdos, como a poesia e o encômio. Nesse sentido, no prefácio de Das Narrativas Verdadeiras, ele explicita que está fazendo algo outro em relação aos filósofos, prosadores (aí incluídos os historiadores) e poetas, que teriam misturado o pseûdos em sua narrativa, sem revelar seu caráter fictício.

A partir de uma outra perspectiva teórica, Isabelle Gassino chega a uma conclusão semelhante em relação ao poder do pseûdos evidenciado nessa obra luciânica, embora ela não faça menção a Brandão na bibliografia. Ainda que afirme que as fronteiras dos discursos se tornam moventes e fluidas segundo a lógica narrativa luciânica, ela conclui que Luciano entra no domínio da literatura, em caráter fundacional, constituindo-o, através do pseûdos como um discurso sem fronteiras, abolindo diferenças entre sentido próprio e figurado ou entre ficçáo e realidade, dentro do relato, e além de tudo, um psếdos que mostra os limites do lógos, muitas vezes pervertendo sua lógica?

Outro parâmetro importante na definiçâo de romance é o seu estatuto de narrativa mista. Partindo do conceito de diégesis em Platão, Brandão aproxima o romance, tanto da história, como da épica. Segundo ele, a prosa romanesca se distingue da prosa historiográfica pelo seu caráter ficcional, o que a aproximaria mais da epopeia, ou seja, seria uma prosificaçáo da épica antes que uma prosa historiográfica ficcionalizada. Caso se mantenha sua proveniência da epopeia, o romance se elaboraria dentro de uma esfera propriamente literária, tendo, por conseguinte, como traço mais característico a ficção e como efeito principal, o prazer ${ }^{8}$. Nos romances, sem dúvida, é notável essa busca de legitimidade literária através de um modo recorrente de evocar temas, estruturas, procedimentos e, às vezes, citaçóes literais dos poemas homéricos, como acontece de forma explí-
6. J.L. Brandão, $A$ invenção do Romance, Brasília,

Editora UNB, 2005, p. 37.

7. I. Gassino, "Par-delà toutes les frontières: le pseudos dans les Histoires vrais de Lucien”, p. 87 98, in F. Mestre, \& G. PILAR, (ed.). Lucian of Samosata, Greek writer and Roman citizen. Barcelona: Publications I Edicions de la Universitat de Barcelona, 2010.

8. BRANDÁO, op. cit., p. 180-182. 
9. TILG, op. cit., p. 217 -

220.

10. BRANDÃO, op. cit., p. 85 . cita no romance de Caríton. Não obstante, o modo de apresentação do narrador muitas vezes mimetiza fórmulas da narrativa historiográfica, por exemplo, os títulos e proêmios dos romances: "Cariton de Afrodisíade, secretário de Atenágoras, o retor, uma paixão amorosa, acontecida em Siracusa, narrarei."(Caríton de Afrodisíade, Calírroe, 1.1.1). Compare-se com o prólogo de Tucídides: "Tucídides de Atenas escreveu a guerra dos peloponésios e dos atenienses (...)"(Tucídides, História, 1.1.1).

O diálogo com o discurso historiográfico é evidente. Cabe, todavia, ser nuançado o tipo de relação pretendida. Que essa relação buscada é relevante demonstra o título encontrado no fragmento do papiro Michaelides 1, datado entre o século II e III d.C., constante do fim do segundo livro: "Livro segundo das narrativas de Caríton de Afrodisíade acerca de Calírroe", o que parece evocar a fórmula historiográfica: "Livro primeiro da história helênica de Xenofonte". O que Brandão argumenta, através de uma análise panorâmica dos processos de composição da narrativa e da constituição da figura do narrador, é que o narrador do romance mimetiza o próprio processo da narração, ou seja, no proêmio, representa-se o próprio narrador. De outra perspectiva, Stefan Tilg também enfatiza o fato de que os diegémata seriam uma forma de reagir sobre essa tradição historiográfica, no sentido de pontuar para o leitor de que não se trata de história, mas de uma categoria narrativa específica do romance 9 . A representaçáo do narrador também se distingue pelo uso do tempo verbal: enquanto, no título, a açáo referida está no passado (pois as narrativas já estão escritas), a ação do narrador aponta para o futuro, ou seja, o relato que será contado e, por sua vez, será acompanhado na leitura pelo leitor da obra ${ }^{10}$.

Os títulos do romance, de maneira usual, apresentam os dois nomes dos protagonistas, como Antia e Habrócomes, ou a variante em -ka, como Ephesiaká, As Efesíacas. No entanto, o fim do texto de Caríton explicita que o tema principal é a figura de Calírroe, tendo a seguinte enunciação: "tais coisas acerca de Callírroe escrevi"; isso levou alguns comentadores a pensarem num título mais antigo em que aparecesse apenas o nome da heroína, Calírroe. Baseado no testemunho do papiro Michaelides 1 e no papel que a concepção de diégesis/narrativa tem no texto, Stefan Tilg propóe como título original: As narrativas sobre Calírroe (Tà perì Kalliróen diegémata). Isso forneceria uma 
vinculação com o título de Luciano, Das Narrativas Verdadeiras, podendo ser uma referência a uma indicação de gênero por parte de Luciano. As narrativas sobre Calírroe, nessa ótica, já manifestariam seu caráter ficcional, em contraposição ao modelo historiográfico que mimetiza. Tanto em Caríton, quanto em Luciano, é estabelecido esse diálogo mimético com uma tradição literária e narrativa, em que o parâmetro ficcional do pseûdos cria um distanciamento do leitor em relação ao narrado, cujo estatuto independe de critérios de verdade.

Então, esse tipo de indagação deve ser dirigido para essas narrativas apócrifas, no sentido de apreciar como estabelecem essa relação com a tradição a que fazem referência e qual o efeito e a o pacto de leitura requerido com o leitor. Eis o início de José e Aseneth:

"E aconteceu que, no primeiro ano dos sete anos de abundância, no quinto dia do segundo mês, o Faraó enviou José para circular/recorrer por toda a terra do Egito." (José e Aseneth, I.1) ${ }^{11}$.

Kaì egéneto é uma fórmula de começo de narrativa típica de vários livros bíblicos, tal como aparece em Neemias, Juízes, Jó, Rute, 2Samuel e 1Macabeus. Dessa forma, o texto já insere o leitor no estilo da narrativa escriturística, buscando uma ambientação histórica pra o seu relato. Além desse cenário histórico construído narrativamente, o que pressupõe uma atitude mimética em relação aos livros escriturísticos considerados históricos, os elementos claramente fictícios da obra levaram alguns comentadores a buscarem um corpus judaico de narrativas romanceadas a que poderia pertencer José e Aseneth. De fato, isto é o que Wills ${ }^{12}$ empreende fazer buscando relacionar e vincular várias dessas narrativas num gênero romanesco judaico, aí incluindo Ester, Judite, Tobit, diversas histórias incorporadas em Antiguidades Judaicas de Flávio Josefo, entre outras, abarcando, é claro, José e Aseneth. Esta perspectiva tem o mérito de levantar um background de histórias de caráter fictício de tradição judaica, ante o qual se pode inferir o caráter pretensamente ficcional desta obra; não obstante, José e Aseneth se destaca do corpus estabelecido por Wills, pois suas características estruturais a vinculam, certamente ao romance antigo, mas não ao pretenso gênero das outras obras judaicas.

Criticando esse gênero romanesco judaico proposto por Wills, Sara Raup Johnson monta um outro tipo de corpus, não pela perspectiva do gênero, mas pelo modo como essas
11. Traduzimos trechos do texto conforme edição de Pius-Ramon Tragan.

12. L.Wills, "The Jewish Novellas.”. in J.R. Morgan, R. Stoneman (Ed.), Greek Fiction: The Greek Novel in Context, London and New York, Routledge, 1994, p. 223-238. 
13. S. R. Johnson, Historical Fictions and Hellenistic Jewish Identity: Third Maccabees in Its Cultural Context (HCS, 43; Berkeley, University of California Press, 2004,

p. xv. "ficções históricas", segundo o termo usado pela autora, mesclam procedimentos característicos de uma historiografia judaico-helenística, com um relato, em maior ou menor grau, da ordem do fictício. Para ela, textos como, por, um lado, Ester, Judite, Daniel, Tobias, como também, a Carta de Aristéias, 2 Macabeus e 3 Macabeus, e, por outro lado, a obra de Artápano e José e Asenet, seriam exemplos dessas ficções históricas que, conscientemente, se utilizariam do discurso historiográfico judaico-helenístico, com o intuito de constituírem uma identidade judaica helenística contemporânea pela reformulação e atualização de seu passado ${ }^{13}$. A autora adverte que, a despeito de José e Asenet ter a forma de romance, uma tal classificação não é admissível sem uma séria qualificação da obra, ou seja, o elemento ideológico, aqui argumentado como finalidades identitárias da comunidade judaica helenística, seria um sério obstáculo para sua inclusão no gênero do romance antigo.

Embora a interpretação de qual seria a finalidade subjacente ao texto seja questão de um debate, em que aspectos como proselitismo e conversão são aventados, é esperável que não se encontre aqui um princípio ficcional da ordem do pseûdos, tal qual concebido a partir do romance antigo, em geral, e da ótica luciânica, em particular. $\mathrm{O}$ que chamo de romance apócrifo parece se orientar em outra direção. Que guia de leitura poderia ser aduzido para um tal tipo de narrativa? Uma das obras analisadas por Sara Johnson, conquanto náo de maneira extensiva, é a obra conhecida como 2 Macabeus, presente no cânon eclesiástico católico, mas não no cânon escriturístico hebraico. Segundo Johnson, uma boa parte das informaçóes de $2 \mathrm{Mac}$ acompanha de maneira verossímil os fatos históricos, porém, há inserçóes de partes claramente ficcionais, como a história relativa ao sacerdote Onias, cuja relevância no relato é bastante enfatizada. O passo, em minha perspectiva, que ilumina o caráter híbrido dessa, por assim dizer, ficção histórica parece até então desapercebido pelos comentadores do texto e é o seguinte:

2,23 “(...) todos estes fatos expostos por Jasão de Cirene em cinco livros tentaremos resumi-lo em um só volume”.2,25 “(...) nos preocupamos em proporcionar divertimento/agrado/encantamento aos que desejam ler, comodidade/facilidade aos que se comprazem em confiar os fatos à memória e vantagem/proveito a todos os que tomam contato com o texto/ aos leitores/ aos que consultam a obra”. (2Macabeus, 2, 23-25) 
Embora composto em fins do século II a.C. (o que, de certa forma estaria próximo, da composição de José e Aseneth, caso recuada), segundo Momigliano, e, segundo Gottwald, juntamente com 1Macabeus, representariam uma resposta judaica ao governo selêucida, e, ademais, a despeito de ser qualificado como pertencente ou como análogo ao gênero historiográfico, essa passagem de 2Macabeus suscita o tipo de questão que vai ser crucial para se pensar o estatuto da prosa judaico-cristã posterior.

Vamos nos ater à letra do texto que autodefine seu discurso como metáfrasis, como transposição, transformação condensadora de outro texto. $\mathrm{O}$ autor se encarregaria de fazer um resumo da obra de Jasão de Cirene, composta de cinco livros. Ele faz questáo de frisar seu grande esforço empreendido na composição do texto e apresenta como parte da finalidade de seu trabalho a fruição estética do leitor, comparado a alguém que vai desfrutar de um simpósio. No contexto da passagem, há uma série de contraposiçóes entre o tipo de ação do autor da história e o tipo de ação do autor da metáfrasis: a ação deste último, por exemplo, é análoga a de pintar e adornar uma casa, enquanto a ação do, por assim dizer, historiador, seria a de construir os alicerces e a parte estrutural do edifício.

A passagem em foco remete a três espécies de recepção e a três tipos de intencionalidade a elas correlatos: divertimento, comodidade para a memorização e proveito. Quanto ao segundo aspecto, apesar de sua importância, vou me abster de comentar em vista de minha falta de referência no tocante ao uso da memória ou de alguma forma de mnemotécnica no contexto judaico; de qualquer forma, isso representava uma parte essencial nos escritos biográficos ou híbridos posteriores, no sentido de fornecer uma prática de si, um treinamento da psykhé que inevitavelmente se serve de uma mnemotécnica discursiva.

Quanto aos outros dois termos, prestam-se a um tipo de enquadramento segundo uma terminologia análoga utilizada por Luciano de Samósata no proêmio de Das Narrativas Verdadeiras:

Assim como para aqueles que se ocupam com atividades atléticas e com a atenção cuidadosa de seus corpos não apenas é mister o cuidado com uma saudável constituição ou com exercícios físicos - portanto, como uma parte do treinamento importantíssima a concebem, mas também com o relaxamento requerido no momento apropriado, assim também, 
justamente, para aqueles que labutam com os discursos, eu considero ser conveniente, depois da abundante leitura de assuntos mais sérios, também relaxar a mente e prepará-la para o esforço mais intenso posteriormente, e seria adequado o descanso para eles, se travassem relaçóes com tais espécies de leitura, as quais, não apenas fornecem um divertimento gracioso e prazeroso, mas também uma certa perspectiva especulativa demonstre não destituída de encanto literário, o que, de certo modo, eu suponho também conceber com estes meus escritos.

Em ambos os textos, a psykhagogia, mais fortemente marcada segundo a concepção platônica do Fedro cujo sentido seria de encantamento e sedução da psykhé, porém, expressando aqui a conotação mais leve de divertimento, indica a distensão produzida por um tal tipo de obra em relação a um gênero de obras mais sérias. Nos dois, o proveito alcança um tipo de leitor que saberá nutrir da obra uma theoría não desprovida de valor artístico, no sentido de se chegar a uma espécie de contemplação do espírito, uma theoría, mesmo que divertida e graciosa. $\mathrm{O}$ proveito especulativo luciânico reflete, como antes comentado, sobre o caráter ficcional construído na relação de alteridade, pactuada com leitores cultos e letrados, com os discursos verdadeiros. O proveito de uma obra judaica (e, num sentido análogo, de uma obra cristã), longe desta perspectiva ficcional, indica o engajamento ideológico associado por Luciano a busca de uma filiação a uma crença ou doutrina e, nesse sentido, se aproxima de uma intencionalidade biográfica segundo a perspectiva luciânica.

Além dessas diferenças, o psêudos, enquanto princípio ficcional, como um dos traços constituintes do romance antigo, está associado e, em grande medida, expresso pelo jogo mimético estabelecido nas várias obras. Com mímesis quero significar, de forma particular, o modo de refiguração da tradição greco-romana, através de um processo de intertextualidade que abarca diversos campos discursivos, no escopo de uma concepção mimética definida em Do Sublime do Pseudo-Longino. No caso do romance antigo, concorrem por exemplo, no juízo dos vários scholars, relaçóes com a epopeia, a historiografia, a comédia nova e a comédia latina, a elegia helenística, os relatos de viagens, entre outros. Consoante a isso, há o recurso a uma atividade mimética ligada ao campo visual com 
inúmeras referências às artes plásticas, como à pintura e à escultura, mas também à refiguração literária de tal imaginário imagético feita pelos escritores. Por exemplo, Quéreas é comparado às estátuas e pinturas (plástai te kaì grafeîs) de Aquiles, Nireu, Hipólito e Alcibíades, numa referenciação cruzada à tradição mítica, poético-dramática e histórica.

É essa atividade mimética, por assim dizer, gráfica de caráter ficcional que se expressa de maneira intensa no momento do primeiro encontro entre os dois enamorados, momento esse marcado pelo páthos sofrido por cada um dos dois personagens, tal qual se expóe no romance de Caríton:

Era a festa de Afrodite, e quase todas as mulheres foram até o templo. Mas, como até então Calírroe não tinha comparecido, sua mãe a conduziu, uma vez que Eros as impelia a fazer a veneração da deusa. E, nessa hora, Quéreas vinha caminhando do ginásio para casa, resplendente como um astro; o rubor do treinamento se alçava ao brilho do seu rosto, como o ouro na prata. Como por acaso, então, numa estreita curva do caminho toparam um ao encontro do outro, uma vez que o deus tinha deliberado esta coincidência de caminho, a fim de que cada um fosse visto pelo outro. Súbito então uma paixão amorosa foi transmitida um em resposta ao outro...a beleza vindo ao par da nobreza.(Calírroe, I, 4-6)

Nessa cena prototípica do romance amoroso, o páthos erotikón é transmitido pela visão. Atinge aqui uma espécie de clímax essa atividade mimética gráfica, fazendo do elemento visual o grande agenciador do páthos e, por conseguinte, do desenrolar da narrativa. No plano da narração, há a ação direta de Eros, como também, em certo grau, de Afrodite. Não obstante, o elemento do acaso ou da sorte está marcado pela expressão ' $e k$ týkhes', expressão essa recorrente no enredo da peça, sinalizando o caráter imprevisto e repentino dos eventos e das açóes dos personagens. Segundo Brandão, é esse agenciamento dos fatos pela fortuna que assinala a especificidade narrativa do romance antigo. Tudo na história, eventos, atos, personagens, é afetado pela ação da fortuna, a afecção amorosa mostrando-se, de certo modo, como um dos aspectos dessa ação narrativamente construída da Týkhe; os personagens sofrem do páthos, assim como são afetados pelos eventos imprevistos e súbitos. 
Cabe então discernir no âmbito do romance ou novela apócrifa o escopo ou a variação desses modos romanescos de compor a tessitura literária, através de uma atividade gráfica mimética e através dos agenciamentos dos fatos pela fortuna. Com efeito, a cena em que Aseneth primeiramente vê e, depois, encontra José revela essa afecção por um páthos visualmente ocorrida:

E viu Aseneth José sobre o carro e ficou fortemente conturbada/aturdida. Sua alma ficou alquebrada e seus joelhos fraquejaram/se soltaram e todo o seu corpo estremeceu e foi acometida por um medo enorme. E se lamentou e disse ao seu coração (...).(José e Aseneth, VI, 1)

Essa cena é análoga, de modo claro, àquela do primeiro encontro entre Quéreas e Calírroe, em que a visão do amado proporciona o páthos que atinge a heroína. Aseneth apresenta os mesmos sinais da paixão amorosa, tanto pela perturbação do espírito quanto pela afecção corporal. Esta cena, não obstante, apresenta um correspondente no passo em que o arcanjo Miguel aparece a Aseneth; as emoções sentidas por ela são as mesmas dessa primeira visão de José e são empregados os mesmos termos. De certa forma, o anjo é apresentado como um duplo de José, pois transparece as mesmas feiçóes físicas desse, porém, já é possível entrever o caráter sincrético desse páthos, aqui misto de paixão amorosa e temor religioso. Outra diferença entre os dois relatos diz respeito àquilo que David Konstan chama de simetria amorosa: tanto a mulher, quanto o homem seriam afetados e em igual medida pela paixão que os deixa praticamente sem ação; isso é exatamente o que acontece com os protagonistas de Caríton: em vista de seu páthos, ficam completamente a mercê da emoção amorosa e, invariavelmente, adoecem em decorrência disso. Por sua vez, enquanto Aseneth representa adequadamente seu papel de heroína de romance, José corresponde minimamente a esse páthos, apenas apiedando-se dela e enunciando uma prece em sua intercessão. Na verdade, a primeira sensação de José é completamente adversa à amada. Com efeito, aproximando-se ela para cumprimentá-lo com um beijo, ele a afasta abruptamente com a mão (posta entre os seios, na versão longa), pois um homem puro e piedoso náo poderia ter contato com 
uma mulher devotada aos ídolos. Aseneth reage a isso, com lágrimas e gemidos o que resulta no compadecimento de José e em sua prece. O que se deve chamar a atenção aqui é concernente às reaçôes de Aseneth, primeiro à vista do esplendoroso José, depois à sua recusa em beijá-la e, em seguida, à enunciação da prece em seu proveito:

E alegrou-se Aseneth com a bênção de José com uma alegria demasiada e se foi com toda a pressa e retirou-se para os seus aposentos no piso superior e ficou caída em sua cama desfalecida, porque havia nela alegria e tristeza, grande medo e agitação e uma transpiração contínua enquanto escutara todas as palavras que José disse a ela em nome de Deus altíssimo. E chorou um longo e amargo pranto e se arrependia dos deuses que venerava e sentiu repulsa dos ídolos e e estava a esperar por vir a noite. (José e Aseneth, IX, 1-2)

Nesse passo se percebe com toda nitidez os dois traços distintos do páthos nesse romance apócrifo, o que o vincula a uma série de textos conhecidos como Atos Apócrifos. Em primeiro lugar, o páthos sentido pela heroína tem, a princípio, dupla face: por um lado, corresponde à paixáo amorosa típica do romance, por outro, vincula-se aos sofrimentos no curso de uma transformação de gênero de vida, exemplificado aqui, pelos sentimentos de arrependimento e penitência da heroína, a qual, durante uma semana, se isola do convívio dos outros, renega sua antiga crença nos deuses egípcios e se penitencia com um severo jejum. O outro aspecto diz respeito ao elemento aural desse páthos apócrifo: os protagonistas do romance grego não precisam emitir nenhuma espécie de juízo, eles simplesmente se vêem e se apaixonam. Aqui, ao contrário, esse páthos que afeta Aseneth, ainda que tenha se iniciado com a visão do amado, atinge seu paroxismo ao ouvir uma prece, que não deixa de ser uma prédica relativa a uma nova doutrina, ou seja, esse páthos diz respeito ao sofrimento decorrente pela conversão a uma nova fé. Isso fica mais patente no caso da obra conhecida como Atos de Paulo e Tecla.

Próximos de uma intencionalidade biográfica e compostos na mesma época que a maior parte da produção luciânica, os Atos Apócrifos dos Apóstolos, perspectivados aqui como romance apócrifo ou narrativa híbrida, expóem ao longo de 
14. Cf. C. Moreschini, Claudio, N., Enrico, Historia da Literatura Cristä Antiga Grega e Latina II - do Concílio de Nicéia ao Início da Idade Média. (Tomo I), trad. Marcos Bagno, São Paulo: Ed. Loyola, 2000; C. Moreschini, Claudio,

N., Enrico, Historia da Literatura Cristã Antiga Grega e Latina I - de Paulo à Era Constantiniana. Trad. Marcos Bagno, São Paulo: Ed. Loyola, 1996; J. Tosaus Abadía, José Pedro, A Bíblia como literatura, trad. Jaime A. Clasen, Petrópolis, Vozes, 2000 .

15. P.J. Lalleman, The Canonical and Aprocryphal Acts of the Apostles, in Groningen Colloquia on the novel, Vol. IX, Egbert Forsten, Groningen, 1998, p. $181-192$ seu enredo um tipo de instrução ideológica que assimila elemento derivados do cristianismo popular da segunda metade do século II d.C. e da ambiência gnóstica que os circundava.

É claro que a formação e composição dos atos apócrifos ocorre numa época, segunda metade do século II e princípios do século III d.C., quando os atos presumivelmente compostos por Lucas estão em fase de canonização ${ }^{14}$, o que indica, por um lado, uma diferença de finalidade e, por outro, uma busca de continuidade e filiação quanto ao gênero. A redação de Lucas, por seu turno, denunciaria um tipo de escrita propriamente historiográfica, preocupada com o cotejo das fontes e filiada a um compromisso com a verdade a ser relatada. Embora explicitando a ênfase dada às práxeis, aos atos e realizaçóes do apóstolo, os atos apócrifos não deixam de buscar uma caracterização biográfica da personalidade do protagonista do relato, tanto na descrição dos traços físicos que o narrador nos apresenta de Paulo, como também de seu caráter através de sua conduta face aos outros, especialmente face a Tecla.

Há toda uma polêmica para se classificar os Atos canônicos segundo um determinado gênero; a despeito de declaraçôes que os assimilam a ficçôes, são qualificados geralmente segundo a rubrica de monografia histórica, que apresentaria uma série de similaridades quanto aos procedimentos técnicos e estilísticos com a historiografia helenística ${ }^{15}$. Por seu turno, os Atos Apócrifos tendem a mimetizar esse tipo de escrita historiográfica cristã, mas não apresentam um interesse de manter qualquer fidelidade histórica dos fatos, deles se utilizando ou mesmo os inventando segundo as necessidades da narrativa. De qualquer forma, é mantido esse compromisso de relatar fatos minimamente comprováveis, com o intuito de oferecer um testemunho de fé, com fins doutrinais e ligado ao culto de santos, mártires e apóstolos,o que de certo modo, vai instaurar toda uma literatura de martírio. Aliás, desses Atos Apócrifos, a parte relativa ao martírio do apóstolo geralmente se destaca do relato e sua transmissão é mais ampla, diversificando sua inserção na tradição manuscrita.

Nos Atos de Paulo e Tecla, a figura de Tecla, não obstante, parece subverter esse compromisso historiográfico elou biográfico do relato, arrastando a narrativa e seus leitores para um outro gênero do discurso, tal qual se mostra no momento de sua inserção no história: 
E depois de Paulo dizer tais coisas em meio à assembléia na casa de Onesíforo, Tecla, uma virgem cuja mãe era Teóclia, noiva de um homem chamado Tamíris, estando sentada à janela bem próxima dessa casa, escutava dia e noite o discurso de Paulo sobre Deus, sobre a castidade, a crença em Cristo e a prece; e nem se movia ela da janela, mas era assim levada pela crença a ficar num estado extremo de regozijo e êxtase. Além do mais, como também visse mulheres e virgens sendo inseridas no convívio de Paulo, ansiava igualmente por ser considerada digna de postar-se face a Paulo e ouvir a palavra de Cristo. De fato, ainda nem tinha visto a figura de Paulo, mas apenas escutado seu discurso.

No entanto, como não deixasse a janela, sua mãe manda chamar por Tamíris; chega ele, então, todo animado, como que esperasse já recebê-la em casamento. Disse então Tamíris a Teóclia: “Onde está a minha Tecla para que eu possa vê-la?' E disse Teóclia: 'Tenho um relato novo e inesperado para te fazer, Tamíris. Com efeito, por três dias e três noites Tecla não se alça da janela, nem para beber nem para comer, mas, com um olhar fixo como que de encantamento, de tal modo se assujeita a um homem estrangeiro, o qual ensina por meio de discursos enganosos e artificiosos, que me espanta como o sentimento de pudor da virgem possa estar táo molestamente perturbado. (Atos de Paulo e Tecla, VII-VIII)

Por um lado, o tratamento estilístico do texto pode parecer denunciar uma elocução simples e descuidada, preservando, como diria Judith Perkins, "um raro acesso a exemplos de uma voz narrativa popular" 16 , o que distanciaria do tipo de composição do romance greco-latino, a princípio, dirigido a pessoas cultas e letradas. No entanto, este tipo de composiçáo estilística pode igualmente denunciar uma mímesis relativa aos escritos evangélicos e epistolares escriturísticos, uma mímesis, portanto, conscientemente buscada do estilo simples e redundante dos evangelhos e atos canônicos.

De uma forma ou de outra, o páthos sentido por Tecla é, a princípio, da mesma ordem e, talvez, num grau ainda mais intenso que a afecção amorosa sentida pela heroína típica do romance grego antigo. Ela é acometida por uma afecção que a deixa incapaz de fazer qualquer coisa, a não ser ouvir o discurso do apóstolo e buscar estar em sua presença. $\mathrm{O}$ personagem
16. J. Perkins, The Suffering Self. Pain and Narrative Representation in the Early Christian Era, London and New York, Routledge, 1995, p. 297. 
17. Holzberg, op. cit., p. 23. da mãe, Teóclia, é que tem a função de explicitar na narrativa a interpretação do estado da filha como algo próprio da paixão amorosa e o termo páthos é utilizado para caracterizar distintamente tal estado, tal afecção.

A posição de teóricos como Holzberg é que, a despeito da criação inegável de uma prosa romanesca cristá, contendo paralelos temáticos com o gênero do romance, quais sejam, jornadas cheias de perigos, resgates na última hora, cenas de tribunal, naufrágios, ela não poderia ser incluída como romance antigo:

As variaçóes sobre o tema dos enamorados acossados por infortúnios demonstram somente que aqui o clima ideológico sofreu uma mudança radical. O lugar dos dois enamorados que juraram fidelidade imperecível é ocupado pelo apóstolo e uma jovem mulher que, por ouvi-lo pregar, converte-se na divulgadora da nova fé e, assim, do amor de Cristo somente; mesmo se já está comprometida com outro, casada, ou ainda solteira, ela agora se compromete com a absoluta castidade ${ }^{17}$.

Nessa linha de análise, a substituição da paixão amorosa pelo tema da castidade alteraria o caráter dessa prosa cristã de tal forma que a lançaria para as margens do gênero do romance antigo, transformando-a assim numa narrativa romanesca marginal. Ao contrário disso, entendo que se trata menos de substituição do que entrecruzamento e hibridismo; a noção de páthos se tornaria, nesse contexto, o fenômeno aglutinador e catalisador dos vários tipos de afecção, paixão e sofrimento. Dessa forma, o páthos de relatos cristáos romanescos, a exemplo do que acontece nos Atos de Paulo e Tecla, mescla o páthos erotikón próprio do romance grego antigo com o sofrimento do mártir no decurso de sua passio. Sob a ótica de leitura aqui adotada em vista da análise de tais textos, a ausência de intercurso sexual, ou melhor, a ênfase no relato de ações demonstrativas de castidade indicam menos a substituição da paixão amorosa do que a intensificação do páthos amoroso na ligação efetiva e afetiva, no caso, com um apóstolo.

Eis os eixos temático-discursivos e, por assim dizer, estruturais, como tenho argumentado, que vinculariam tais narrativas cristás ao gênero romanesco: o pseûdos enquanto princípio ficcional, o páthos erotikón, a paixão amorosa, e a 
ocorrência de parádoxa, de fenômenos extraordinários, conduzidos pela ação da fortuna (cf. Brandão, 1996). A partir daí, procedo a análise do enredo dos Atos de Paulo e Tecla:

No início do texto, temos a chegada de Paulo na cidade de Icônio, onde vai ser recebido e hospedado por Onesíforo, um cristáo piedoso. Na casa deste homem é que Paulo faz suas várias prédicas, por que é veiculada a doutrina cristá abordando assuntos, como a ressurreição de Cristo e a necessidade da manutenção da castidade. Como já foi referido, essa ênfase numa determinada instruçáo e, de certa forma, num engajamento ideológico, já distanciaria esse relato do romance, mas um detalhamento maior das variáveis em jogo pode levar a resultados mais nuançados. Aliás, seria esperável que uma narrativa cristã, numa época em que o cristianismo está em confrontação radical com o conglomerado cultural greco-romano circundante, tenda a assimilar para o enredo elementos dessa confrontação e a adaptar os elementos romanescos para seu contexto sócio-cultural. De qualquer forma, um cuidado com o elemento religioso, com sua própria forma de culto pagão, é encontrado igualmente nos romances gregos, em que os dois protagonistas enamorados são tanto piedosos, nas suas obrigaçóes com as divindades e em seus atos rituais, quanto castos, a castidade representando uma função crucial para a dinâmica da narrativa.

Há elementos novos, no entanto, empregados, como a prece, que advém de uma forma judaica de compor a história $^{18}$, como vimos em José e Aseneth; a prece, nesse sentido, adquire uma função importante, pois seu aparecimento introduz mudança no curso dos eventos, assim como traduz a intervenção da instância divina ${ }^{19}$. Talvez, por esse critério, se possa distinguir efetivamente um relato cristáo do romanesco: enquanto neste último a esfera da fortuna (uma espécie de representação do acaso em forma narrativa) é a grande agenciadora dos eventos, das aventuras e desventuras dos heróis, naquele, por outro lado, a instância divina, na forma de providência, conduz o destino dos personagens de maneira esperável. É claro que num romance há, de forma bem explícita, a açáo dos deuses, como Afrodite e Eros, mas eles se manifestam menos como divindades do que como figurações de categorias do sentir, ou mesmo, como meros agentes da fortuna. A ação da fortuna não estaria completamente ausente nesses relatos. Tanto nos Atos de Tecla, quanto em José e
18. Cf. N.K.Gottwald, Introdução Socioliteraária à Bíblia Hebraica, trad. Anacleto Alvarez; rev. H. Dalbosco, São Paulo, Paulus, 1988.

19. K. Berger, As Formas Literárias do Novo Testamento, trad. Fredericus Antonius Stein, supervisão Johan Konings, São Paulo, Ediçôes Loyola, 1998, p. 324. 
Aseneth, a visão da mulher provoca uma reação súbita: nessa segunda história, o filho do Faraó se apaixona por Aseneth, o que tem como efeito todas as desventuras posteriores da esposa de José; na outra narrativa, um jovem rico, Alexandre, se apaixona por Tecla e a reação rude desta ao assédio do jovem ocasiona a hostilidade do pretendente ultrajado e os insucessos posteriores. O que há de coincidente nos vários relatos é que os jogos da sorte e a instabilidade daí advinda são postos na trama quando se trata de descrever a açáo dos adversários. Se a providência divina sempre auxilia apóstolo e heroínas, o campo de ação dos antagonistas está muitas vezes no registro da Týkhe, das inesperadas obras do acaso.

Não obstante, o trecho que citamos inicialmente parece buscar uma relação inequívoca com o romance, pois, aos olhos da mãe Teóclia, como já foi dito, Tecla está acometida por um páthos de caráter erótico, sendo que o termo páthos é repetidamente usado para descrever o estado da filha. Deve-se ter em conta, contudo, que tal caracterizaçáo vem a partir do ponto de vista antagonista, ou seja, do ponto de vista que o narrador quer definir como distorcido e afastado da verdadeira realidade. Tanto assim que dessa mesma perspectiva, Paulo é considerado, assim como Pedro no outro relato, sedutor e enganador das mulheres e, por conseguinte, como mago, feiticeiro, que era uma das acusaçóes que, por exemplo, Celso dirigia às figuras de Cristo e Moisés. O páthos aqui retratado adquire assim uma conformaçâo mista: por um lado, diz respeito à paixão amorosa, em função de uma interpretação relativa ao imaginário dos leitores de romances; por outro,diz respeito à afecção própria do recém-convertido, aqui retratada como alheamento e êxtase, mas podendo vir a ter uma conotação de penitência, sofrimento e arrependimento.

No tipo de romance grego ideal, os personagens sofrem de um páthos que os atinge e os afeta de uma forma total e absoluta. Isso vale também para Tecla (e para uma personagem como Aseneth), mas o páthos, nesse caso, vincula, irresistivelmente, noçóes cruciais do ensinamento moral cristão e judaico. No contexto judaico, temos como exemplo a obra José e Aseneth; nesta narrativa, como vimos, a paixão de Aseneth por José é arrebatadora, embora, a princípio, não haja reciprocidade. Todavia, essa afecção, enquanto páthos erotikón, que a consome e oprime, leva-a a um processo de isolamento, 
purgação e penitência, a partir de que ela se arrepende de sua anterior devoção aos deuses egípcios e se converte à religião judaica. Aseneth, como Tecla, de certo modo passa por um processo de dupla afecção: há primeiramente o seu sentimento por José, em que fica no estado emocional típico da heroína apaixonada; depois é acometida pelos sofrimentos próprios de alguém que está na iminência da conversão, o que significa dizer isolamento, jejum, arrependimento, penitência, desapego radical de valores antigos, angústia.

De uma forma ou de outra, tanto para Aseneth, quanto para Tecla, o páthos agencia e compartilha, juntamente com a paixão amorosa, uma outra espécie de vinculação semântica e pragmática, resultando num tipo de sentimento marcado pela adesão a um sofrimento buscado, o sofrimento do convertido que se penitencia, o páthos do mártir cuja vida se expóe conforme um testemunho público e teatral desse páthos, que não deixa de ser e definir a própria narrativa.

Neste trabalho, fiz questão de relacionar as narrativas de Aseneth e de Tecla ao romance grego, mas, sobretudo, buscando uma vinculaçáo de gênero entre as duas. Há uma enorme polêmica sobre a datação de José e Aseneth, cujo estado da questáo pode ser visto em Pius-Ramon Tragan. A maior parte dos especialistas a situa entre os séculos I a.C. e II d. C., muito embora Ross Kraemer argumente para uma dataçáo bem posterior, séculos III-IV d.C. Nesse sentido, esse texto se revela essencial para se discutir o estatuto romanesco para tais narrativa apócrifas. Caso anterior ou mesmo contemporâneo a Caríton, ele serve como paradigma de uma vertente romanesca de caráter doutrinário ligado ao tema da conversão, com uma tendência biografizante e hagiográfica; caso datado depois, ele náo deixará de ser importante como uma forma romanesca de propagar uma doutrina religiosa, cujo enredo representa, a princípio, uma conversão a um novo credo. Aliás, segundo Kraemer, a transmissão do texto de José e Aseneth (sem me ater às questóes referentes a diferenças e avaliação das recensóes curta e longa) ocorreu em meio cristão e não se tem evidência de ter sido transmitido por judeus. Sua influência se faz sentir na tradição hagiográfica cristâ: os relatos de martírio de Santa Irene, Santa Bárbara e Santa Cristina parecem dever muito às narrativas de Aseneth, em sua estrutura narrativa e em seu eixo temático. 
20. D. Konstan, Love in the Ancient Novel and Related Genres, Princeton, New Jersey, Princeton University Press, 1994.

21. P.W. Dunn, Peter W. 1993. Women's Liberation, The Acts of Paul, and other Apocryphal Acts of the Apostles, Apocrypha, Paris, 4, 1993, p. 245-261;

J.-D. Kaestlin, Jean-

Daniel. Fiction littéraire et réalite sociale: que peut-on savoir de la place des femmes dans le milieu de production des Actes Apocryphes des apôtres?, Apocrypha, Paris, 4, 1990, p. 279-302.
Deve-se chamar a atenção para a relevância do papel feminino de Tecla, bem mais central e focalizado que o de Paulo, em correspondência com a ênfase dada ao personagem feminino no romance grego de tipo ideal. No entanto, não se pode achar aqui o que David Konstan chama de simetria amorosa ${ }^{20}$, uma vez que Tecla, na posição de discípula do apóstolo, sempre é enquadrada numa posição hierarquicamente inferior, ainda que seja a protagonista propriamente dita da narrativa. Há, na verdade, toda uma polêmica acerca do que teria sido o papel das mulheres na produção e recepção desse tipo de narrativa ${ }^{21}$, mas é inegável que a represe ntação da ação, da posição e de todo um imaginário relativo à mulher toma aqui uma dimensão bem maior e mais elaborada do que em outros tipos de relato.

Os Atos de Paulo e Tecla e José e Aseneth representam uma espécie correlata dos romances antigos, com a predominância do páthos erotikón, em um, e da conjunção de páthos e narrativa de parádoxa, no outro. A instabilidade da Týkhe, que movia a narrativa romanesca, é ocupada tanto pela providência divina, quanto pela disputa entre a prática religiosa pagã e os emissários da nova doutrina, o que dinamiza o relato numa perspectiva testemunhal e biográfica e o estrutura numa composição estilística redundante e simples. Esse tipo de romance híbrido ou, por assim dizer, apócrifo, misto de biografia e romance, fora do cânone romanesco antigo, não deixa de exibir sua natureza espetacular numa narrativa que pressupóe a repetição do drama cristão encarnado pelos novos heróis da época, mártires, santos, apóstolos e apóstolas. O páthos aí representado, além do sentido de afecção amorosa próprio do romance grego canônico, integra e assimila os valores judaico-cristãos concernentes a penitência, sofrimento e conversão a uma nova fé. Um enquadramento narrativo com elementos biográficos se interpóe face sua configuração ficcional, orientando sua recepção para seu aspecto testemunhal e direcionando o gênero romanesco para a dimensão biográfica de um conhecimento, cuidado e apropriação de si a partir de uma narrativa que se quer paradigmática a um certo modo de vida e que, nas obras aludidas, diz respeito a refiguraçóes e expressóes do discurso feminino da época.

Érrose. 